\title{
UJI VARIASI DOSIS PERASAN LENGKUAS (Alpinia galanga) TERHADAP PERTUMBUHAN KUMAN Staphylococcus aureus
}

\author{
Evy Ratnasari Ekawati ${ }^{1)}$, Prasetyo Handriyanto ${ }^{2)}$ \\ ${ }^{1)}$ Dosen Fakultas Ilmu Kesehatan, Universitas Maarif Hasyim Latif, Sidoarjo \\ ${ }^{2)}$ Dosen Akademi Farmasi, Surabaya \\ Email : evysains@gmail.com
}

\begin{abstract}
Infections caused by Staphylococcus aureus if not handled effectively will be able to cause death human. Hasn't been found effective antibacterial against Staphylococcus aureus. Antibacterial active compounds in the essential oil of ginger have the ability as an antimicrobial, so it can be used as an antibacterial. This study aims to determine effectiveness of the juice of galangal (Alpina galanga) to the growth of Staphylococcus aureus. This study was an experimental study using disc diffusion method. The juice galangal (Alpina galanga) used has dosage of $10 \%, 20 \%, 30 \%, 40 \%, 50 \%, 60 \%, 70 \%, 80 \%, 90 \%$ and $100 \%$. At dosage of $50 \%$ to $100 \%$ has the potential to inhibit the growth Staphylococcus aureus. Nonetheless, based on the statistical test dosage of $50 \%, 60 \%, 70 \%$, and $80 \%$ was significantly different from dosage $90 \%, 100 \%$, and positive control and negative control. Dosage $90 \%$ and $100 \%$ was not significantly different, making more used dosage $90 \%$ to accelerate the process of growth inhibition Staphylococcus aureus.
\end{abstract}

Keyword : the juice of galangal (Alpina galanga), Staphylococcus aureus

\section{PENDAHULUAN}

Staphylococcus aureus merupakan merupakan mikroba dengan habitat alami pada manusia di daerah kulit, mukosa hidung, mulut dan usus besar, dimana dalam kondisi sistem imun normal, Staphylococcus aureus tidak bersifat pathogen (mikroflora normal manusia) (Prescott, et al., 2005). Dapat dikatakan hubungan kuman Staphylococcus aureus dengan manusia adalah simbiosis komensalisme (Salyers and Whitt, 2002). Staphylococcus aureus merupakan jenis bakteri paling virulen dari keluarga
Staphylococcus bila masuk ke dalam saluran pencernaan pada luka yang terbuka (Bowersox, 1999).

Toksin yang dihasilkan kuman Staphylococcus aureus (staphilotoksin, staphylococcal enterotoxin dan exfoliatin) memungkinkan organisme ini menyelinap pada jaringan dan tinggal dalam waktu yang lama pada daerah infeksi, menimbulkan infeksi kulit minor, seperti jerawat, impetigo, cellulitsfollicitus, kulit mengelupas, hingga penyakit mematikan seperti pneumonia, meningitis, 
osteomyelitis, endocarditis dan toxic shock syndrome (Bowersox, 2007).

Beberapa kasus infeksi yang disebabkan oleh Staphylococcus aureus, bila tidak ditangani secara efektif akan dapat menimbulkan kematian pada manusia, seperti toxic shock syndrome (Forbes, dkk., 1998; Lindsay, dkk., 1998). Belum ditemukan ada antibakteri yang efektif terhadap Staphylococcus aureus. Kontrol infeksi lebih ditujukan pada tindakan menjaga kebersihan (WHO, 2004).

Penggunaan antibiotik berulangulang dan tidak tepat, merupakan penyebab utama peningkatan jumlah bakteri yang resisten terhadap antibiotik. Penggunaan antibiotik secara cerdas dan tepat adalah kunci pengendalian penyebaran kuman yang resisten terhadap antbiotik (Anonim, 2011).

Kasus resistensi Staphylococcus aureus terhadap bahan antibakteri juga dilaporkan dalam beberapa penelitian. Penelitian dari Chang dkk (2003) menyatakan bahwa ditemukan isolat Staphylococcus aureus yang resisten terhadap vancomisin. Menurut Waters (2011), sebanyak $96 \%$ isolat Staphylococcus aureus pada peternakan di Amerika telah resisten terhadap minimal satu jenis antimikroba, diantaranya tetrasiklin, ampisilin, penisilin, erythromisin, quinopristin, fluoroquinolones, oxasillin dan daptomisin.

Lengkuas (Alpinia galangal L.) merupakan anggota familia Zingeberaceae. Di Indonesia, lengkuas mudah diperoleh dan sering dimanfaatkan sebagai obat herbal. Lengkuas (Alpinia galanga L.) di Thailand dimanfaatkan sebagai zat aditif pada makanan dan negara-negara lain di
Asia lengkuas sudah lama dimanfaatkan untuk menyembuhkan penyakit rematik, radang selaput lendir hidung, bronkial, bau mulut, bisul, pilek, batuk rejan pada nakaanak, infeksi tenggorokan dan demam. Kandungan 1'-Acetoxychavicol acetat pada lengkuas (Alpinia galanga L.) memiliki kemampuan sebagai antimikroba yang sangat baik (OONmetta-aree, et al. 2006; Vuddhakul, V. 2007; Rao, K. 2010).

Minyak atsiri dari Lengkuas (Alpinia galanga L.) telah terbukti memiliki aktivitas penghambatan terhadap dermatofita tertentu, jamur berfilamen dan yeast (Mohd, M.S. 2003). Suganya dan Sombat telah melaporkan bahwa potensial tertinggi sebagai antioksidan dan antimikroba pada lengkuas (Alpinia galanga L.) karena adanya beberapa senyawa, yaitu 1,8-cineole, 4-allyphenyl acetat dan $\beta$-bisabolene dalam minyak atsiri (Perez, C. et al. 1990; Rao, K. 2010).

Berdasarkan uraian di atas, perlu dilakukan penelitian mengenai uji variasi dosis perasan lengkuas (Alpinia galanga) terhadap pertumbuhan kuman Staphylococcus aureus, sehingga dapat diketahui dosis minimum perasan lengkuas yang dapat membunuh kuman Staphylococcus aureus.

\section{METODOLOGI PENELITIAN}

Jenis penelitian ini adalah eksperimental laboratorium. Rancangan penelitian yang digunakan adalah Rancangan Acak Lengkap (RAL) dengan 11 perlakuan dan masing-masing perlakuan terdiri dari 3 kali ulangan. Data yang diperoleh diuji secara statistik untuk mengetahui adanya beda nyata antar 
perlakuan, serta disajikan dalam bentuk tabel.

\section{Waktu dan Tempat Penelitian}

Pengambilan sampel lengkuas dilakukan pada lahan toga pemukiman penduduk daerah Gubeng Surabaya. Sedangkan penelitian dilakukan di Laboratorium Bakteriologi Fakultas Ilmu Kesehatan UMAHA Sidoarjo.

\section{Alat dan Bahan Penelitian}

Cawan petri, blank disk, swab steril, ose mata, pinset, jangka sorong, beaker glass, blender, penyaring, pipet ukur, gelas ukur, Mueller-Hinton Agar (MHA), Nutrient Agar Slant (NAS), PZ steril, aquadest steril, Ciprofloxacin $500 \mathrm{mg}$, isolate Staphylococcus aureus ATCC 25923.

\section{Prosedur}

\section{Sterilisasi}

Semua alat dan bahan yang akan dgunakan disterilisasi terlebih dahulu menggunakan autoclave suhu $121^{0} \mathrm{C}$ selama 15 menit.

\section{Preparasi Sampel}

Lengkuas (Alpina galangal L.) dicuci sampai bersih dari tanah, kemudian dikeringkan dengan cara diangin-anginkan, kemudian diblender sampai halus. Lengkuas yang telah halus diperas dan filtratnya ditampung pada beaker glass bersih dan steril.

\section{Preparasi Larutan Uji}

Dibuat larutan uji dengan dosis $10 \%$, $20 \%, 30 \%, 40 \%, 50 \%, 60 \%, 70 \%, 80 \%$, $90 \%$ dan $100 \%$ dengan cara dipipet $0,1 \mathrm{ml}$; $0,2 \mathrm{ml} ; 0,3 \mathrm{ml} ; 0,4 \mathrm{ml} ; 0,5 \mathrm{ml} ; 0,6 \mathrm{ml} ; 0,7$ $\mathrm{ml} ; 0,8 \mathrm{ml} ; 0,9 \mathrm{ml}$; dan $1 \mathrm{ml}$ air perasan lengkuas, kemudian masing-masing dilarutkan dalam $1 \mathrm{ml}$ aquades steril.

\section{Preparasi Kontrol}

Control positif dibuat dari sediaan tablet Ciprofloxacin $500 \mathrm{mg}$ yang digerus kemudian ditimbang dan disetarakan dengan $500 \mathrm{mg}$, selanjutnya dilarutkan dalam $100 \mathrm{ml}$ aquades steril. Control negatif menggunakan aquadest steril.

\section{Pembuatan Suspensi Bakteri Uji}

Isolate bakteri Staphylococcus aureus ATCC 25923 yang telah diremajakan diambil 2-3 koloni dengan menggunakan ose mata steril dan disuspensikan kedalam tabung berisi $2 \mathrm{ml} \mathrm{PZ} \mathrm{steril.} \mathrm{Suspense} \mathrm{di}$ vortex, kemudian kekeruhan di samakan dengan standart Mc Farland 0,5 (Tumane, et al., 2014).

\section{Uji Aktivitas Antibakteri Rebusan Lengkuas}

Blank disk direndam pada larutan uji rebusan lengkuas pada masing-masing dosis dan pada larutan Ciprofloxacin 500 mg selama 15 - 20 menit. Disiapkan cawan petri steril untuk masing-masing perlakuan, dituangkan $10 \mathrm{ml}$ MHA ke dalam cawan petri kemudian biarkan memadat. Pada media MHA yang telah memadat diletakkan maksimal 5 disk yang telah direndam dalam masing-masing dosis air perasan lengkuas dengan jarak antar disk $1,5 \mathrm{~cm}$. Perlakuan yang sama untuk kontrol positif dan negatif. Semua cawan petri diinkubasi pada suhu $37^{\circ} \mathrm{C}$ selama 24 jam. Pengamatan adanya zona hambat yang terbentuk setelah inkubasi dan diukur diameternya menggunakan jangka sorong. 


\section{HASIL DAN PEMBAHASAN}

\section{Hasil}

Hasil uji variasi dosis perasan lengkuas (Alpina galangal L.) dengan konsentrasi 10\%, 20\%, 30\%, 40\%, 50\%, $60 \%, 70 \%, 80 \%, 90 \%$ dan $100 \%$ terhadap kuman Staphylococcus aureus ATCC 25923, menunjukkan bahwa perasan lengkuas (Alpina galangal L.) pada dosis $50 \%$ hingga $100 \%$ memiliki potensi dalam menghambat pertumbuhan mikroba uji. Meskipun demikian, berdasarkan uji statistik, dosis 50\%, 60\%, 70\% dan $80 \%$ berbeda nyata dengan dosis $90 \%, 100 \%$, kontrol negatif dan kontrol positif. Dosis $90 \%$ dan $100 \%$ tidak berbeda nyata dengan kontrol positif. Sedangkan dosis $90 \%$ tidak berbeda nyata dengan dosis $100 \%$. Karena dosis $90 \%$ dan dosis $100 \%$ tidak berbeda nyata, maka lebih efektif menggunakan dosis 90\% untuk menghambat proses pertumbuhan kuman Staphylococcus aureus ATCC 25923. Pengaruh perasan lengkuas terhadap pertumbuhan kuman Staphylococcus aureus ATCC 25923 terlihat dari diameter zona hambat yang terbentuk (Tabel 1).

Tabel 1. Rata-rata Diameter Zona Hambat Perasan Lengkuas (Alpina galangal L.) terhadap kuman Staphylococcus aureus ATCC 25923

\begin{tabular}{cc}
\hline $\begin{array}{c}\text { Dosis Perasan Lengkuas } \\
\text { (Alpina galangal L.) }(\%)\end{array}$ & $\begin{array}{c}\text { Diameter Zona Hambat } \\
(\mathbf{m m})\end{array}$ \\
\hline Kontrol $(+)$ & $20^{\mathrm{f}}$ \\
\hline 0 & $0^{\mathrm{a}}$ \\
\hline 10 & $0^{\mathrm{a}}$ \\
\hline 20 & $0^{\mathrm{a}}$ \\
\hline 30 & $0^{\mathrm{a}}$ \\
\hline 40 & $0^{\mathrm{a}}$ \\
\hline 50 & $8^{\mathrm{b}}$ \\
\hline 60 & $10^{\mathrm{c}}$ \\
\hline 70 & $12^{\mathrm{d}}$ \\
\hline 80 & $14^{\mathrm{e}}$ \\
\hline 90 & $16^{\mathrm{f}}$ \\
\hline 100 & $18^{\mathrm{f}}$
\end{tabular}

Keterangan : angka diameter zona hambat yang diikuti oleh huruf yang tidak sama adalah berbeda nyata pada uji Duncan taraf 5\%

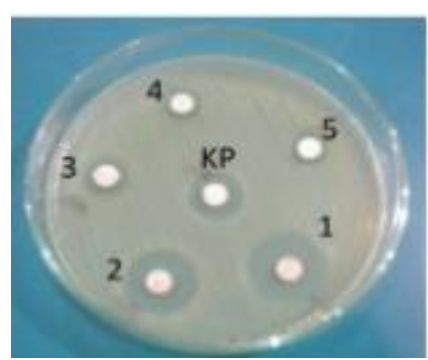

Gambar 1. Zona hambat perasan lengkuas terhadap Staphylococcus aureus yang terbentuk setelah inkubasi 
Uji varisi dosis perasan lengkuas (Alpina galangal L.) dengan berbagai variasi dosis, didapatkan hasil terbentuknya zona hambat. Diameter zona hambat yang terbentuk sebesar $8 \mathrm{~mm}$ hingga $18 \mathrm{~mm}$, dari dosis 50\% hingga 100\%. Zona hambat maksimum sebesar 18 mm dicapai pada dosis $100 \%$.

\section{Pembahasan}

Terbentuknya zona hambat dikarenakan perasan lengkuas (Alpina galanga) memiliki senyawa aktif yang bersifat sebagai antimikroba. Lengkuas merupakan tanaman popular di Asia Tenggara, termasuk Indonesia, mengandung minyak atsiri yang bersifat antimikroba, antifungi dan antioksidan (Hsu, 2010; Siregar, et al.,2014). Minyak atsiri pada lengkuas (Alpina galangal L) mengandung senyawa aktif, diantaranya 8,8-sineol, $\alpha$ dan $\beta$-pinen, terpinen-4-ol, limonene, $\alpha$-terpineol, $\alpha$-pinen, $\alpha$-tujon, geranil asetat, $\alpha$-bergamoten, trans- $\beta$ farnesen, $\beta$-bisabolen dengan konsentrasi masing-masing komponen lebih dari $4 \%$ (Schaeffer, et al., 1981 dan Pooter, et al., 1985).

Menurut Pamungkas (2010), minyak atsiri aktif sebagai antibakteri, karena senyawa kimia tersebut mengandung gugus fungsi hidroksil $(-\mathrm{OH})$ dan karbonil. Menurut Heyne (1987) dan Parwata (2008), senyawa turunan hidrokarbon teroksigenasi (fenol) memiliki daya antibakteri yang kuat. Senyawa fenol dapat menghambat peetumbuhan bakteri dikarenakan turunan fenol berinteraksi dengan sel bakteri melalui proses adsorpsi yang melibatkan ikatan hydrogen. Pada kadar rendah membentuk kompleks protein fenol dengan ikatan yang lemah dan segera mengalami peruraian, diikuti penetrasi fenol ke dalam sel dan menyebabkan presipitasi serta denaturasi protein. Pada kadar tinggi fenol menyebabkan koagulasi protein dan sel membran akan mengalami lisis (Luftana, 2009).

\section{KESIMPULAN}

Berdasarkan hasil penelitian, didapatkan hasil bahwa perasan lengkuas (Alpina galangal L.) pada konsentrasi 90\% memiliki potensi maksimal dalam menghambat pertumbuhan kuman Staphylococcus aureus ATCC 25923 dengan diameter zona hambat sebesar 16 $\mathrm{mm}$.

\section{UCAPAN TERIMAKASIH}

Penulis mengucapkan terimakasih pada Staf Laboratorium Bakteriologi Fakultas Ilmu Kesehatan UMAHA Sidoarjo yang telah banyak membantu dalam penelitian ini

\section{DAFTAR PUSTAKA}

Bowersox, J. 1999. Experimental Staph Vaccine Broadly Protective in Animal Studies. NIH.

Bowersox, J. 2007. Experimental Staph Vaccine Broadly Protective in Animal Studies. NIH.

Chang, S., Sievert, D.M., Hageman, J.C., Boulton, M.L., Tenover, F.C., Downes, F.P., Shah, S., Rudrik, J.T., Pupp, G.R., Brown, W.J., Cardo, D., and Fridkin, S.K. 2003. Indection With Vancomycin-Resistant Staphylococcus aureus Containing The vanA Resistance Gene. New 
England. Journal of Medicine. 348 : 1342-1347.

Forbes, B.A., Sahm, D.E., and Weissfeld, A.S. 1998. Diagnostic Bacteriology. Tenth Edition. Mosby Inc. Missouri.

Heyne, K. 1987. Tumbuhan Berguna Indonesian. Jilid I dan II. Terj. Badan Litbang Kehutanan. Cetakan 1. Koperasi Karyawan Departemen Kehutanan. Jakarta Pusat.

Hsu, W.Y., Simonne, A., Weissman, A. and Jeong-Mok Kim. 2010. Antimicrobial Activity of Greater Galangal (Alpina galanga (Linn.) Swartz) Flowers. Food Sciences Biotechnol. 19 (4) : 873-880.

Luftana, Y.K. 2009. Minyak Atsiri dari Rimpang Lengkuas. http://www.blogspot.minyak-atsiridari-rimpang-lengkuas $<<$ yis'sFOOD-entertaining.htm. Diakses Oktober 2016.

Mohd, M.S., Chin, C.B., Chen, L.L., and Sim, N.L. 2003. Journal of Pharmaceutical Biology. 41(5) : 302307.

Oonmetta-aree, J., Suzuki, T., Gasaluck, P., and Eumkeb, G. 2006. Food Science and Technology. 39 (10) : 1214-1220.

Pamungkas, R.N., Julaichah, D., Prasasti, S.D., dan Muslih, M. 2010. Pemanfaatan Lengkuas (Alpina galangal L.) sebagai Bahan Pengawet Pengganti Formalin. PKM. Univ. Negeri Malang.

Parwanta, I.M.D., dan Dewi P.F.S. 2008. Isoalasi dan Uji Aktivitas Antibakteri Minyak Atsiri dari Rimpang Lengkuas (Alpina galangal L.). Jurnal Kimia. 2(2) : 100-1004.
Perez, C., Pauli, M., and Bezerque, P. 1990. Acta Biologic et Medicine Experimentalis. 15 : 113-115.

Pooter, H.L., M. Nor Omar, B.A., Coolsaet and N.M. Scamp. 1985. The Essential Oil of Greater Galangal (Alpina galangal) from Malaysia. Phytochem. 24 : 93.

Prescott, L.M., J.P. Harley and D. Aktein. 2005. Microbiology. $6^{\text {th }}$ Edition. Mc. Graw Hill Companies, Inc. Boston. Amerika.

Rao, K., Bhuvaneswari, Narasu, L.M., and Giri, A. 2010. Antibacterial Activity of

Alpina galangal (L)

Willd Crude Extracts. Appl. Biochem Biotechnol. 162 : 871-884.

Salyers, A.A., and D.D. Whitt. 2002. Bacterial Phatogenesis. $2^{\text {nd }}$ Edition. ASM Press.

Scaeffer, J.J.C., A. Ghani, and A. Baerheim-Svendsen. 1981. Monoterpenes in the Essential Rhizome Oil Alpina galangal (L) Wild. Journal of Pharm. 49 :337.

Siregar, B.H., W. Hasan, S. Dharma. 2014. Pemanfaatan Lengkuas (Alpina galanga) dalam Mengawetkan Bakso. FKM. UNSU. Medan.

Tumane, P.M., Meshram, V.G., Wasnik, D.D. 2014. Cmparative Study of Antibacrial ctivuty of Peel Extracts of Citrus aurantium L. (bitter orange) and Citrus medica L. (lemon) Against Clinical Isolates from Wound Infection. International Journal of Pharma and Bio Sciences. $5(1)$ : 382-387.

Vuddhakul, V., Bhoopong, P., Hayeebilan, F., and Subhadhirasakul, S. 2007. Food Microbiology. 24 (4) : 413-418. 
Waters, A.E., Contente-Cuomo, T., Buchhagen, J., Liu, C.M., Watson, L., Pearce, K., Foster, J., Bawers, J., Driebe, E.M., Engelthaler, D.M., Keim, S.P., and Price, L.B. 2011. Multi Drug-Resistant Staphylococcus aureus in US Meat and Poultry Clinical Infectious Disease. Arizona.

World Health Organization. 2004. Guidelines for Drinking-Water Quality. 3 ${ }^{\text {rd }}$ Edition. Geneva. 